\title{
A surgical technique for secondary repair of obstetric anal sphincter injuries; sphinctero-vagino-perineoplasty
}

\section{Obstetrik anal sfinkter hasarinin sekonder onariminda cerrahi teknik; sfinktero-vajino-perineoplasti}

\author{
(D) Arife Şimsek, (1) Mustafa Ateş, (1) Abuzer Dirican, (1) Dinçer Özgör \\ İnönü University Faculty of Medicine, Department of General Surgery, Malatya, Turkey
}

\begin{abstract}
Objective: This study was conducted to present the preliminary results of seven patients treated with sphinctero-vagino-perineoplasty for secondary repair of obstetric anal sphincter injuries.

Materials and Methods: This retrospective study was conducted on the records of seven patients who underwent secondary repair of obstetric anal sphincter injuries at the colorectal surgery unit of a tertiary care center between February 2015 and December 2017.

Results: All patients with solid stool incontinence were fully recovered at postoperative month 3 . The Wexner incontinence score was significantly improved (decreased from 14.12 [range: 8-20] to 2.28 [range: 1-4]). The complication rate was $85.7 \%$ (wound infection, abscess, hematoma, detachment). Conclusion: Combined repair of anal sphinchters, perineal body, superficial transverse perineal muscles, and bulbospongious muscles, which contribute to anal continence, may improve surgical outcomes in patients with obstetric anal sphincter injuries.
\end{abstract}

Keywords: Anal incontinence, obstetric anal sphincter injury, perineoplasty, sphincteroplasty, vaginoplasty

$\ddot{O} z$

Amaç: Bu çalışma obstetrik anal sfikter hasarının sekonder onarımında sfinktero-vajino-perineoplasti uygulanan yedi hastanın erken dönem sonuçlarını bildirmek amaciyla yapıldı.

Gereç ve Yöntemler: Obstetrik anal sfikter hasarı nedeniyle sekonder onarım planlanan ve Şubat 2015-Aralık 2017 tarihleri arasında bir üniversite hastanesinin kolorektal cerrahi ünitesinde sfinktero-vajino-perineoplasti uygulanan yedi hastanın kayttları geriye dönük incelendi.

Bulgular: Postoperatif 3. ayda hiçbir hastada katı gaita inkontinansı gözlenmedi. Wexner inkontinans skorunda belirgin düzelme (14,12'den [aralık: 8-20] 2,28'e [aralık: 1-4] geriledi) izlendi. Hastaların \% 85,7'sinde komplikasyon (infeksiyon, abse, hematom, detaşman) gelişti.

Sonuç: Anal kontinansı oluşturan yapıların (anal sfinkterler, perineal body, süperfisyal transvers perineal kaslar, bulbospongiosus kaslar) kombine onarımı obstetrik anal sfinkter hasarının sekonder onarımında daha iyi sonuçlar edilmesine imkan sağlayabilir.

Anahtar Kelimeler: Anal inkontinans, obstetrik anal sfinkter hasarı, perineoplasti, sfinkteroplasti, vajinoplasti

\section{Introduction}

The most common cause of anal incontinence in women is obstetric anal sphincter injuries (OASIS). Clinically apparent OASIS occur in less than 3 percent of vaginal deliveries $^{(1)}$. In spite of primary repair, up to $5 \%$ of these patients develop anal incontinence, which severely impairs their quality of life ${ }^{(2,3)}$. When OASIS is treated for anal incontinence, it is considered as a secondary repair even if no primary repair has been performed during the postpartum period $^{(4)}$. There is no consensus on which surgical technique is

PRECIS: We present the preliminary results of seven patients treated with sphinctero-vagino-perineoplasty for secondary repair of OASIS.

Address for Correspondence/Yazıșma Adresi: Arife Şimșek, MD,

İnönü University, Faculty of Medicine, Department of General Surgery, Malatya, Turkey

Phone: +90 5364764197 E-mail: draksimsek@yahoo.com.tr ORCID ID: orcid.org/0000-0002-4807-3597

Received/Geliș Tarihi: 15.05.2018 Accepted/Kabul Tarihi: 05.09.2018

${ }^{\circledR}$ Copyright 2018 by Turkish Society of Obstetrics and Gynecology

Turkish Journal of Obstetrics and Gynecology published by Galenos Publishing House 
effective for secondary repair of OASIS ${ }^{(5)}$. Unfortunately, longterm consequences of surgical interventions (sphincteroplasty, perineorrhaphy, and transposition of muscle flaps) are unsatisfactory. All of these techniques are focused on either isolated anal sphincter repair, or reconstruction of tissue supporting the anal canal with the anal sphincter unrepaired. We believe that the damage to the perineal body, superficial transverse perineal muscles, and bulbospongiosus muscles, which provide contribution to anal continence, is ignored, especially in direct surgical repair. Therefore, the success rates of conventional techniques focused on anal sphincter repair for OASIS are low. In this study, we present the preliminary results of a surgical technique that involves combined restoration of vaginal, perineal, and anal sphincter muscles, for secondary repair of OASIS.

\section{Materials and Methods}

The medical records of 7 women who underwent secondary repair of OASIS at a colorectal surgery unit of a tertiary care center between February 2015 and December 2017 were reviewed. Prior to the surgery, endoanal ultrasonography (EAUS) was performed to measure the degree of sphincter defect. Wexner incontinence scores (WIS) were recorded in both the preoperative and postoperative periods. Postoperative complications and follow-up periods were also recorded. The menstrual cycle was taken into account. Progesterone supplements were given to delay menstruation in the postoperative period. Sexual intercourse was prohibited for 3 months postoperatively.

\section{Surgical technique}

All patients underwent surgery in the lithotomy position under spinal anesthesia. First, a semicircular incision was made matching the projection of the anal sphincter. The second U-shaped incision was made on the posterior commissure of the bulbospongiosus muscles (Figure 1). The vaginal mucosa was dissected to a depth of $6 \mathrm{~cm}$, extending laterally to the bulbospongiosus and puborectal muscles and inferiorly to the perineal body. The anorectal mucosa was dissected from the sphincter muscles at a depth of $5 \mathrm{~cm}$. The anal sphincters were dissected free with at least a depth of $4 \mathrm{~cm}$ (Figure 2). The retracted ends of the sphincters were identified and repaired using the overlapping method using $3 / 0$ polydioxanone sutures. The perineal body was formed on the external anal sphincter (EAS) and the anus was centralized by end-to-end repair of the free ends of the bulbospongiosus muscles (Figure 3). A subcutaneous Penrose drain was placed. Anoderm, vagina, and perineal skin were sutured with absorbable materials. V-Y advancement flaps were used in patients with tissue defects between the vagina and anus (Figure 4). Protective ileostomy was performed only in cases where tissue loss of the anal canal and vagina (cloaca-like deformity) were noticed.

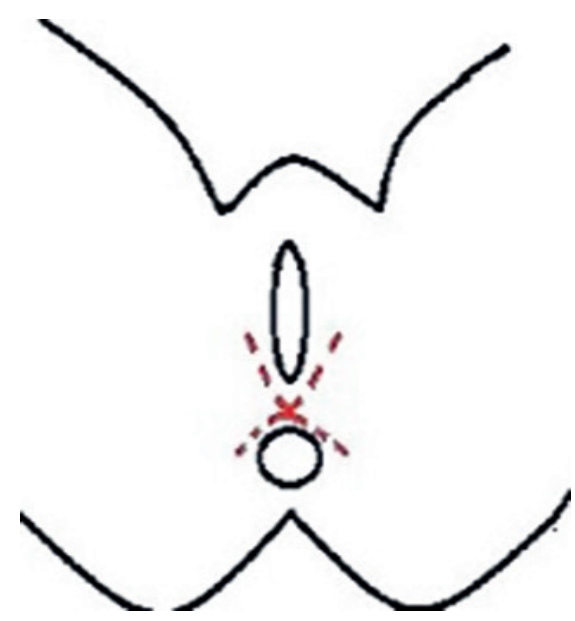

Figure 1. A semicircular incision matched the projection of the bulbospongiosus muscles

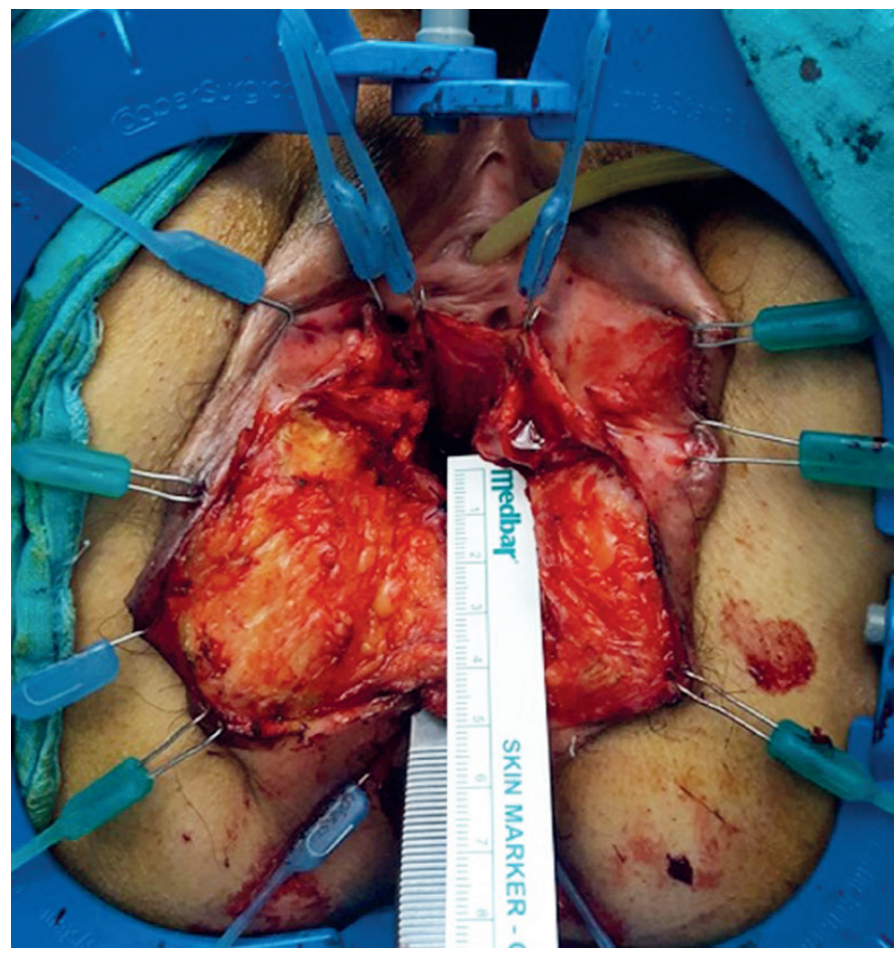

Figure 2. The vaginal mucosa was dissected at a depth of $6 \mathrm{~cm}$, extending laterally to the bulbospongiosus and puborectal muscles and inferiorly to the perineal body. The anorectal mucosa was dissected from the sphincter muscles at a depth of $5 \mathrm{~cm}$. The anal sphincters were dissected free with at least a depth of $4 \mathrm{~cm}$

\section{Statistical Analysis}

Statistical Package for the Social Sciences 17.0 for Windows Data was used. Descriptive frequencies were applied.

This study was conducted according to the principles of the 1975 Helsinki Declaration, which was revised in 2000. Informed consent was obtained from patients. 


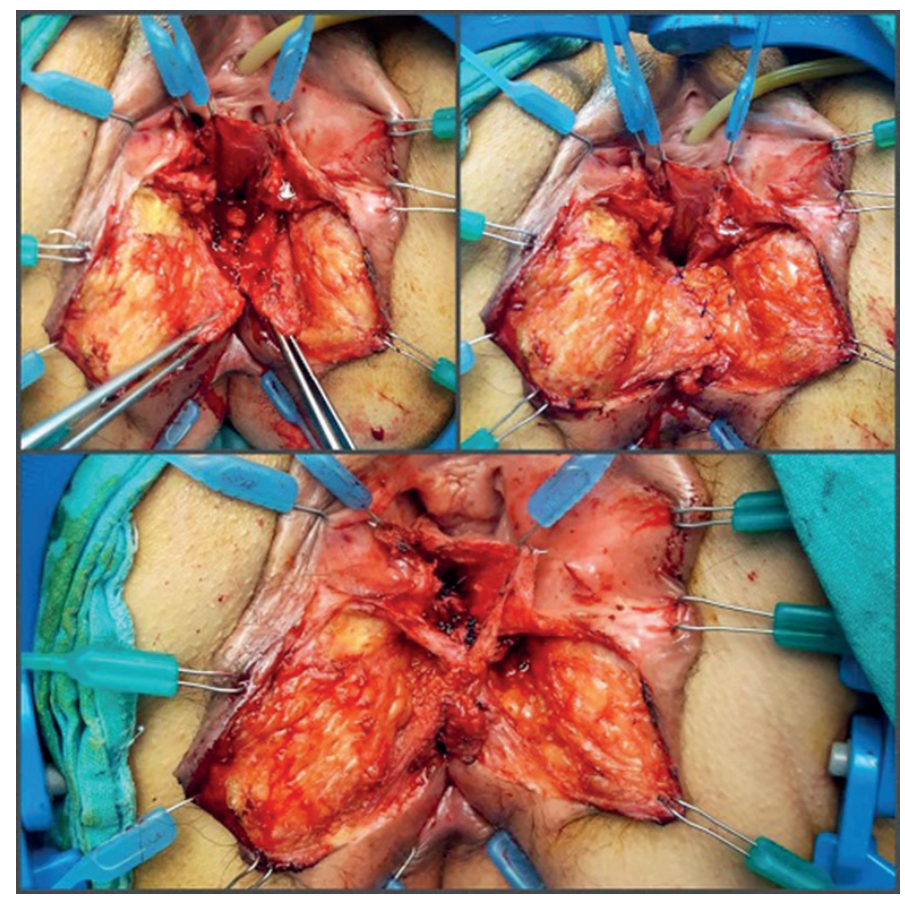

Figure 3. The retracted ends of the sphincters were repaired using the overlapping method. The perineal body was formed on EAS and the anus was centralized through end-to-end repair of the free ends of the bulbospongiosus muscles.

The study was approved by the İnönü University Local Ethics Committee (approval number: 2017/12-6). Informed consent forms were completed by all participants.

\section{Results}

The average age of the women was 34.85 (range, 23-42) years, the average parturition number was 3.14 (range, 1-7), and the mean body mass index (BMI) was 27.14 (range, 22.7$30.4) \mathrm{kg} / \mathrm{m}^{2}$. All patients had a history of vaginal delivery. They developed symptoms of anal incontinence immediately after their first vaginal birth, and gradually worsened in the following births. The mean duration of symptoms was 39.4 (range, 6-120) months. EAUS showed both complete defect of EAS and complete and/or partial defect of the internal anal sphincter (IAS) in 6 patients. There was EAS defect only in one patient. The anal sphincter defect angle did not exceed 130 degrees in any patient. One patient reported incontinence to gas and liquid, and six patients reported incontinence to solid stool, liquid, and gas (Table 1). All six patients with solid stool incontinence were fully recovered at postoperative month 3. The mean preoperative WIS was 14.42 (range, 8-20), whereas it was 2.28 (range, 1-4) at postoperative month 3. The postoperative complications (wound infection, abscess, detachment, hematoma) developed in 6 patients (85.7\%). $\mathrm{V}-\mathrm{Y}$ advancement flaps were used in two of these patients, and free skin flap transfer was performed in one patient. The

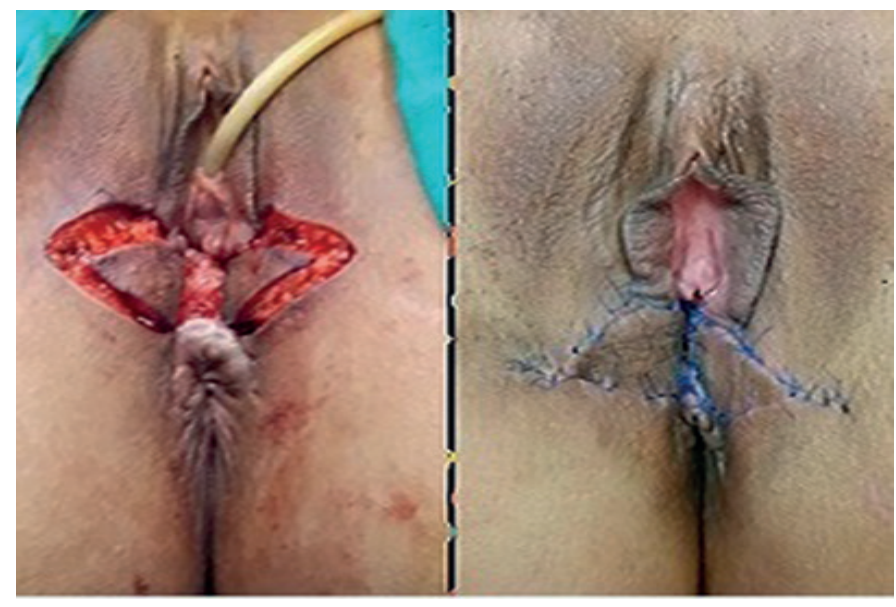

Figure 4. V-Y advancement flap between the vagina and the anus

average follow-up duration was 12.28 (range, 3-26) months.

\section{Discussion}

There are no randomized controlled trials comparing primary and secondary repair of OASIS due to ethical obstacles ${ }^{(6)}$. Based on observational studies, results of primary repair, especially performed by experienced surgeons, are superior to secondary repair ${ }^{(7,8)}$. Direct techniques include reconstruction of the sphincter itself, either by end-to-end or overlapping methods $s^{(9,10)}$. Indirect techniques include reconstruction of striated muscles or fasciae surrounding anal canal, and transposition of a striated muscle flap ${ }^{(11-13)}$. In the literature, surgical techniques are focused primarily on isolated anal sphincter repair ${ }^{(9,10,14,15)}$. Although short-term results of sphincteroplasty are satisfactory with $75-86 \%$ improvement in incontinence, they attenuate with time notifying that less than 50 percent of patients are still continent after $5-10$ years ${ }^{(16)}$. The retraction of sphincters and overlooked pudendal injury may predispose to failure in sphincteroplasty ${ }^{(15,17,18)}$. Indirect methods in which anal sphincters remain unrepaired have poor functional results. The muscles supporting the anal canal necessitate conscious voluntary effort, so it is difficult to maintain continence for prolonged periods, and impossible during sleep ${ }^{(17)}$. As a result, the success rates of conventional surgical techniques decrease with time after surgery ${ }^{(19-21)}$. All of these techniques are focused on either isolated anal sphincter repair, or reconstruction of tissue supporting the anal canal without anal sphincter repair. We believe that the damage to the perineal body, superficial transverse perineal muscles, and bulbosupongiosus muscles, which provide contribution to anal continence, is ignored, especially in direct surgical repair. In the present study, all patients with solid stool incontinence were fully recovered at postoperative month 3. The improvement in WIS was statistically significant. Although complications were high they were resolved properly. We performed diverting colostomy in only two patients because diverting colostomy was not obligatory 
Table 1. The characteristics of patients

\begin{tabular}{|c|c|c|c|c|c|c|c|}
\hline Characteristics & pl & p2 & p3 & $\mathrm{p} 4$ & p5 & p6 & p7 \\
\hline Age & 23 & 37 & 42 & 39 & 35 & 38 & 30 \\
\hline BMI & 24 & 27.5 & 31.2 & 27 & 22.7 & 30.4 & 27.2 \\
\hline Number of vaginal births & 1 & 2 & 4 & 6 & 2 & 4 & 1 \\
\hline $\begin{array}{l}\text { Time interval since the first vaginal } \\
\text { birth [months }(\mathrm{m}) \text { /years }(\mathrm{y})]\end{array}$ & $6 \mathrm{~m}$ & $8 \mathrm{y}$ & $19 \mathrm{y}$ & $16 y$ & $13 y$ & $25 y$ & $5 y$ \\
\hline Duration of symptoms (month) & 6 & 12 & 120 & 6 & 12 & 60 & 60 \\
\hline Preoperative WIS & $8 / 20$ & $16 / 20$ & $17 / 20$ & $14 / 20$ & $13 / 20$ & $20 / 20$ & $13 / 20$ \\
\hline Postoperative WIS (at $3^{\text {rd }}$ month) & $1 / 20$ & $2 / 20$ & $1 / 20$ & $3 / 20$ & $2 / 20$ & $3 / 20$ & $4 / 20$ \\
\hline \multicolumn{8}{|l|}{ Complications } \\
\hline Wound infection & + & + & - & + & + & + & + \\
\hline Abscess & - & - & - & - & + & + & + \\
\hline Hematoma & - & - & - & - & + & - & - \\
\hline Detachment & + & + & - & + & + & + & + \\
\hline Diverting ostomy & - & - & + & - & - & + & - \\
\hline V-Y advancement flap transfer & + & - & - & - & + & - & - \\
\hline Free skin flap transfer & - & - & - & - & - & + & - \\
\hline
\end{tabular}

in the treatment of OASIS. Venkatesh et al. ${ }^{(22)}$ also reported favorable results of combined surgery in 44 patients with traumatic cloaca, the majority of which were secondary to obstetric injuries. They used puborectalis interposition, sphincteroplasty and perineal body repair. All patients except five, had regained both fecal and gas continence. Five women also improved following biofeedback therapy. Anaraki et al. ${ }^{(23)}$ performed sphincteroplasty and perineoplasty with skin advancement flap to reform the perineal body in 19 women with traumatic cloacal defects. Significant improvement in FI scores (decreased from 12.7 to 2.6), quality of life (increased from mean of 45 to 95), dyspareunia (decreased from mean of 5 to 0.8 ) and sexual function satisfaction (increased from mean score of 0.2 to 4.7) in these patients encouraged them to recommend this technique as an effective surgical method. Their complication rate was $15.7 \%$ (wound infection in 2 patients, rectovaginal fistula in one patient), which was managed conservatively. In the current study, although the FI score was significantly improved (decreased from 14.12 to $2.28)$, the complication rate was higher (85.7\%).

\section{Conclusion}

Although the small sample size and absence of longterm results were limitations of this study, the satisfactory preliminary results encourage us to consider that combined repair of anal sphincters, perineal body, superficial transverse perinei muscles, and bulbospongiosus muscles may improve surgical outcomes in patients with OASIS.

\section{Ethics}

Ethics Committee Approval: The study was approved by the İnönü University Local Ethics Committee (approval number: 2017/12-6).

Informed Consent: Consent form was filled out by all participants.

Peer-review: Externally peer-reviewed.

\section{Authorship Contributions}

Surgical and Medical Practices: M.A., A.D., Concept: A.Ş., M.A., A.D., D. Ö., Design: A.Ş., M.A., A.D., D.Ö., Data Collection or Processing: A.Ş, M.A., Analysis or Interpretation: A.Ş, M.A., A.D., D.Ö, Literature Search: A.Ş., Writing: A.Ş.

Conflict of Interest: There is no conflict of interest.

Financial Disclosure: The authors declared that this study received no financial support.

\section{References}

1. Zetterstrom JP, Lopez A, Anzen B, Dolk A, Norman M, Mellgren A. Anal incontinence after vaginal delivery: a prospective study in primiparous women. British Journal of Obstetrics and Gynaecology 1999:324-330.

2. Grigoriadis T, Mylona SC, Giannoulis G, Athanasiou S, Antsaklis A. Sonographic Evaluation of Obstetric Anal Injuries. Donald School Journal of Ultrasound in Obstetrics and Gynecology 2015;9:266-274.

3. Fitzpatrick M, Fynes M, Cassidy M, Behan M, O'Connell PR, O'HerilhyC. Prospective study of the influence of parity and operative technique on the outcome of primary anal sphincter repair following obstetrical injury. Eur J Obstet Gynecol Reprod Biol. 2000;89:159163. 
4. Sultan A.H. (2003) Primary and Secondary Anal Sphincter Repair. In: Stanton S.L., Zimmern P.E. (eds) Female Pelvic Reconstructive Surgery. Springer, London.

5. Fernando RJ, Sultan AH, Radley S, Jones PW, Johanson RB. Management of obstetric anal sphincter injury: a systematic review \& national practice survey. BMC Health Serv Res. 2002;13;2:9.

6. Edozien L. Primary versus secondary repair of obstetric anal sphincter injury Clinical Risk 2005;11:51-52.

7. Sultan AH, Kamm MA, Hudson CN. Obstetric perineal tears: an audit of training. J Obstet Gynaecol 1995;15:19-23.

8. Schofield PF, Grace R. Faecal incontinence after childbirth. Clinical Risk 1999; 5:201-204.

9. Besnard C, Bohec C, Dehni N, Collet M, Homer L. How I do. . the management of fourth degree perineal injury following vaginal delivery? Gyne' col Obsté t Fertil 2009;37:664-668.

10. Zutshi M, Tracey TH, Bast J, Halverson A, Na J. Ten-year outcome after anal sphincter repair for fecal incontinence. Dis Colon Rectum. 2009;52:1089-1094.

11. Felt-Bersma RJ, Cuesta MA. Fecal incontinence 1994: which test and which treatment? Neth J Med. 1994;44:182-188.

12. Whitehead WE, Wald A, Norton NJ. Treatment options for fecal incontinence. Dis Colon Rectum. 2001;44:131-142; discussion 142-144.

13. Conzo G, Brancaccio U, Esposito MG, Miranda G, Palazzo A, Stanzione F, Celsi S, Livrea A. Surgical treatment of fecal incontinence secondary to obstetric trauma.Ann Ital Chir. 2006;77:241-246.

14. Johnson E, Carlsen E, Steen TB, Backer Hjorthaug JO, Eriksen MT, Johannessen HO. Short- and long-term results of secondary anterior sphincteroplasty in 33 patients with obstetric injury. Acta Obstet Gynecol Scand. 2010;89:1466-1472.

15. Rothbarth J, Bemelman WA, Meijerink WJ, Buyze-Westerweel ME, van Dijk JG, Delemarre JB. Long-term results of anterior anal sphincter repair for fecal incontinence due to obstetric injury/with invited commentaries. Dig Surg. 2000;17:390-393; discussion 394.

16. Saldana Ruiz N, Kaiser AM. Fecal incontinence - Challenges and solutions. World Journal of Gastroenterology. 2017;23:11-24.

17. Browning GG, Motson RW. Anal sphincter injury. Management and results of Parks sphincter repair. Annals of Surgery. 1984;199:351357.

18. Neill ME, Parks AG, Swash M. Physiological studies of the anal sphichter musculature in fecal incontinence and rectal prolapse. Br J Surg 1981;68:531-536.

19. Fitzpatrick M, O'Herlihy C. Short-term and long-term effects of obstetric anal sphincter injury and their management. Curr Opin Obstet Gynecol 2005;17:605-610.

20. Dudding TC, Vaizey CJ, Kamm MA. Obstetric anal sphinchter injury: incidence, risk factors, and management. Ann Surg. 2008;247:224237.

21. Zetterström J, López A, Anzén B, Norman M, Holmström B, Mellgren A. Anal sphincter tears at vaginal delivery: risk factors and clinical outcome of primary repair.Obstet Gynecol. 1999;94:21-28.

22. Venkatesh KS, Ramanujam P. Surgical treatment of traumatic cloaca. Dis Colon Rectum1996;39:811-816.

23. Anaraki Fakhrolsadat, Etemad Omid. Sphincteroplasty and perineoplasty with skin advancement flap in management of traumatic cloacal defect. J. Coloproctol. (Rio J.) 2017;37:18-24. 